\title{
Isolation and Characterization of the Tubular Organelles Induced by Fumarate Reductase Overproduction in Escherichia coli
}

\author{
By M. LYNN ELMES, DOUGLAS G. SCRABA AND JOEL H. WEINER* \\ Department of Biochemistry, University of Alberta, Edmonton, Alberta T6G 2H7, Canada
}

(Received 7 October 1985; revised 30 December 1985)

\begin{abstract}
Strains of Escherichia coli amplifying the intrinsic membrane enzyme fumarate reductase accommodate the overproduced enzyme by increasing the amount of membrane material, in the form of intracellular tubular structures. These tubules have been observed in strains harbouring multicopy $f r d$ plasmids and in ampicillin hyper-resistant strains. A procedure has been developed for isolation of tubules nearly free of cytoplasmic membrane. Using protein A-gold labelling and optical diffraction of electron micrographs, a model for tubule structure is proposed. The tubules have a lower lipid/protein ratio than the cytoplasmic membrane, with the enzyme accounting for greater than $90 \%$ of the protein in the tubules. Both cytoplasmic membranes and tubules from amplified strains are enriched in cardiolipin and have a more fluid fatty acid composition than wild-type strains. Mutants defective in cardiolipin synthesis produce tubules in response to excess fumarate reductase, but these tubules have an altered appearance, indicating that lipid-protein interactions may be important for tubule assembly.
\end{abstract}

\section{INTRODUCTION}

Fumarate reductase is a complex iron-sulphur flavoenzyme which serves as the terminal electron transfer enzyme when Escherichia coli is grown anaerobically on fumarate-containing medium (Haddock \& Jones, 1977). The enzyme, composed of a membrane-extrinsic catalytic domain and a membrane-intrinsic anchor domain, consists of four non-identical subunits in equimolar amounts (Lemire et al., 1982, 1983). The expression of fumarate reductase is greatly amplified in strains harbouring multicopy frd plasmids (Cole \& Guest, 1980; Grundström \& Jaurin, 1982; Lemire et al., 1982; Lohmeier et al., 1981) and in ampicillin hyper-resistant strains due to tandem duplications of the chromosomal amp-frd region (Cole \& Guest, 1979a, b). In amplified strains, the enzyme can account for up to $70 \%$ of the inner membrane protein (Weiner et al., 1984). The cells respond to the excess fumarate reductase by increasing phospholipid biosynthesis, thus maintaining a relatively constant lipid/protein ratio (Weiner et al., 1984). The excess lipid and protein is organized in long tubular structures within the cytoplasm of the host bacteria (Lemire et al., 1983; Weiner et al., 1984).

In a recent paper (Weiner et al., 1984), we examined the lipid and protein composition of a fumarate reductase-enriched crude membrane fraction composed of tubules and cytoplasmic membrane. A large increase in the cardiolipin content, as well as an increase in fatty acids of lower melting temperature, was observed. In this paper we describe a method for isolating an enriched tubule fraction and report a structural and chemical characterization. Tubule formation in a cardiolipin-biosynthesis defective mutant and an amp-frd tandem duplication strain has also been examined.

\section{METHODS}

Strains and plasmids. E. coli $\mathrm{HBl} 01\left(\mathrm{~F}^{-} \mathrm{HsdR}^{-} \mathrm{HsdM}^{-} \mathrm{Pro}^{-} \mathrm{Leu}^{-} \mathrm{Gal}^{-} \mathrm{Lac}^{-} \mathrm{Thi}^{-} \mathrm{RecA}^{-}\right)$was from our laboratory stock collection. E. coli G800 (Ilv $\mathrm{GetB}^{-}$ampAl) was provided by Professor J. R. Guest (University of Sheffield, UK). E. coli TIGP $\left(\mathrm{F}^{-} \mathrm{Cls}^{-} \mathrm{MdoA}^{-} \mathrm{Ilv}^{-} \mathrm{Met}^{-} \mathrm{LacI}^{-}\right.$) was provided by Dr E. P. Kennedy (Harvard 


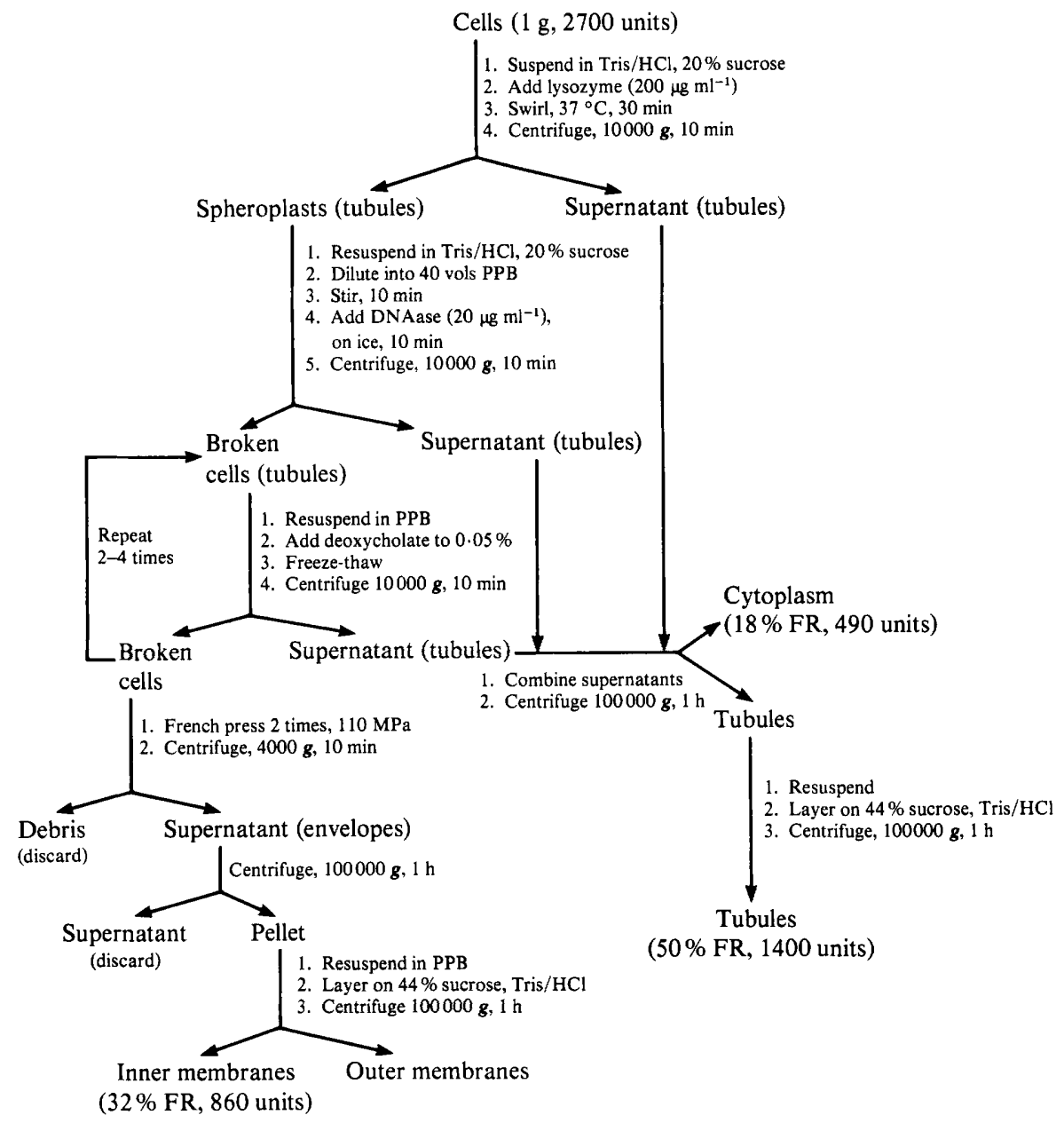

Fig. 1. Flow chart for the isolation of tubules, inner and outer membranes, and cytoplasmic fractions. Details are described in text. FR, Fumarate reductase activity; PPB, potassium phosphate buffer.

Medical School, Cambridge, Mass., USA). Plasmid pFRD63, carrying the frd operon in pBR322, has been described previously (Lemire et al., 1982).

Growth conditions. Cells were grown to late stationary phase $(72 \mathrm{~h})$ anaerobically on glycerol fumarate medium (Spencer \& Guest, 1974) in medium containing $100 \mu \mathrm{g}$ ampicillin $\mathrm{ml}^{-1}$ and necessary vitamin and amino acid requirements. G800 was grown in medium containing $800 \mu \mathrm{g}$ ampicillin $\mathrm{ml}^{-1}$.

Transformation of TIGP. E. coli T1GP cells were treated with calcium and transformed with pFRD63 DNA as described previously (Lemire et al., 1982). Transformants were selected on Luria broth agar plates, containing $100 \mu \mathrm{g}$ ampicillin $\mathrm{ml}^{-1}$.

Isolation of tubules and membranes. Late stationary phase cells ( $1 \mathrm{~g}$ wet weight) were washed once with $50 \mathrm{mM}$ Tris/ $\mathrm{HCl}, \mathrm{pH} 7 \cdot 5$, and suspended in $20 \mathrm{ml} 50 \mathrm{~mm}$-Tris $/ \mathrm{HCl}, \mathrm{pH} \mathrm{7.5,20 \%}$ (w/v) sucrose (see Fig. 1). Lysozyme was added to $200 \mu \mathrm{g} \mathrm{ml}^{-1}$. The solution was swirled slowly at $37^{\circ} \mathrm{C}$ for $30 \mathrm{~min}$, and centrifuged at $10000 \mathrm{~g}$ for $10 \mathrm{~min}$. EDTA was not routinely added, as it was not essential for spheroplast formation (Owen et al., 1982) under the conditions used. This procedure resulted in some cell lysis; thus the supernatant contained cytoplasmic constituents, including a portion of the tubules. The spheroplasts and broken cells were suspended in a minimal volume of $50 \mathrm{mM}-\mathrm{Tris} / \mathrm{HCl}, \mathrm{pH} 7 \cdot 5$, containing $20 \%$ (w/v) sucrose, and the spheroplasts lysed by rapid dilution

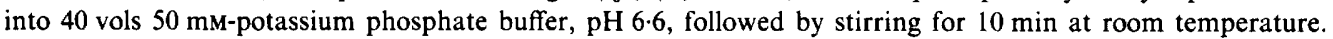
DNAase was added to $20 \mu \mathrm{g} \mathrm{ml}^{-1}$, and the suspension was put on ice for $10 \mathrm{~min}$ and then centrifuged at $10000 \mathrm{~g}$ for $10 \mathrm{~min}$. The supernatant from the broken cell preparation also contained tubules. The broken cells, still containing some tubules, were suspended in $5 \mathrm{ml} 50 \mathrm{~mm}$-potassium phosphate buffer $/ 0.05 \%$ deoxycholate and stored at $-20^{\circ} \mathrm{C}$ for $18 \mathrm{~h}$. The suspension was thawed and centrifuged at $10000 \mathrm{~g}$ for $10 \mathrm{~min}$. The residual tubules 
were removed from the cells by repeating the deoxycholate-freezing steps two to four times. The tubules were collected from all of the low-speed supernatants by centrifugation at $100000 \mathrm{~g}$ for $1 \mathrm{~h}$ at $4{ }^{\circ} \mathrm{C}$ and suspended in 1 to $2 \mathrm{ml}$ Tris/ $\mathrm{HCl}$. The supernatant from the high-speed spin contained small tubule fragments, enzyme aggregates and soluble fumarate reductase.

Lysed spheroplasts were suspended in $4 \mathrm{ml} 50 \mathrm{~mm}$-potassium phosphate buffer, $\mathrm{pH} 6.6$, and crude membranes were prepared by two passages through a French pressure cell at $16000 \mathrm{lbf} \mathrm{in}^{-2}(110 \mathrm{MPa})$. The membranes were collected by centrifugation at $100000 \mathrm{~g}$ for $1 \mathrm{~h}$ and suspended in 1 to $2 \mathrm{ml} \mathrm{Tris} / \mathrm{HCl}$. The high-speed supernatant from the French press sample contained soluble components.

Tubules and inner membranes were further purified by a modification of the procedure of Yamato et al. (1975). Fractions $(1 \mathrm{ml})$ of tubules or envelopes were layered on $6 \mathrm{ml} \mathrm{44 \% (w/w)} \mathrm{sucrose,} 50 \mathrm{mM}-\mathrm{Tris} / \mathrm{HCl}, \mathrm{pH} \mathrm{7.5}$, and centrifuged at $100000 \mathrm{~g}$ for $1 \mathrm{~h}$ at $4{ }^{\circ} \mathrm{C}$ in a Beckman Ti50 fixed angle rotor. Both tubules and inner membranes formed an amber band near the top of the sucrose layer which was removed with a bent Pasteur pipette. The outer membranes pelleted through the sucrose. The tubules and membrane fractions were suspended in 2 vols $50 \mathrm{~mm}-$ Tris $/ \mathrm{HCl}, \mathrm{pH} \mathrm{7.5}$, collected by centrifugation at $100000 \mathrm{~g}$ for $1 \mathrm{~h}$ and each suspended in $1 \mathrm{ml} 50 \mathrm{~mm}-\mathrm{Tris} / \mathrm{HCl}$, $\mathrm{pH} 7.5$, and stored frozen at $-70^{\circ} \mathrm{C}$.

Enzyme assays. Fumarate- and nitrate-dependent oxidation of reduced benzyl viologen was monitored as previously described (Dickie \& Weiner, 1979). One unit of activity corresponds to $1 \mu \mathrm{mol}$ benzyl viologen oxidized $\min ^{-1}$.

ATPase was assayed by measuring the release of inorganic phosphate as described by Owen et al. (1982). One unit corresponds to $1 \mu \mathrm{mol} \mathbf{P}_{\mathrm{i}}$ released $\mathrm{min}^{-1}$.

Protein determination. Protein was estimated by an SDS modification of the Lowry method (Markwell et al., 1978), using Bio-Rad protein standard.

$S D S-P A G E$. Electrophoresis on 12 to $17 \%(\mathrm{w} / \mathrm{v})$ acrylamide gradient gels was done using the Laemmli buffer system (Laemmli, 1970), with the addition of $20 \%(\mathrm{w} / \mathrm{v})$ sucrose to the lower gel solution. Gels were stained, destained and scanned as described previously (Lemire et al., 1982).

Extraction of membrane lipids. Total lipids were quantitatively extracted from purified cytoplasmic membranes prepared from strains HB101(pBR322), HB101(pFRD63), T1GP(pFRD63), and tubules from strain HB101(pFRD63) by a modification of the method of Bligh \& Dyer (1959) as outlined previously (Weiner et al., 1984).

Analysis of fatty acids by GLC. Methyl esters of fatty acids were prepared by transesterification of lipids (Gander et al., 1962) as described previously (Weiner et al., 1984).

Quantification of membrane phospholipids. Individual phospholipids were separated by two-dimensional TLC on glass plates coated with silica gel G (BDH Chemicals Canada) in solvent systems of (i) chloroform/methanol $/ 7 \mathrm{M}$ ammonium hydroxide $(60: 35: 5$, by vol.) and (ii) chloroform/methanol/acetic acid $(65: 25: 8$, by vol.). Lipids were located by exposure of the plates to iodine vapour. The area corresponding to each lipid was removed and eluted with chloroform/methanol $(2: 1, \mathrm{v} / \mathrm{v})$. Phospholipid phosphorus was determined by the method of Raheja et al. (1973).

Protein A-gold labelling and negative-stain electron microscopy. Samples were labelled with colloidal gold using the procedure of Roth et al. (1978) with the following modifications. The colloidal gold was prepared as described by Frens (1973). The protein A-gold complex was prepared by mixing $9 \mathrm{ml}$ colloidal gold with $1 \mathrm{mg}$ protein A (Sigma) dissolved in $0 \cdot 1 \mathrm{ml} \mathrm{H} 2 \mathrm{O}$, followed by the addition of polyethylene glycol $\left(M_{\mathrm{r}} 20000\right)$, as outlined by Roth (1983). Samples were diluted with 10 mm-potassium phosphate buffered isotonic saline (PBS; pH 7.4), 1\% (w/v) bovine serum albumin (BSA ; Miles Laboratories) and allowed to adhere to hydrophilic carbon films on grids. The grids were floated, sample side down, on $100 \mu \mathrm{l}(2.2 \mu \mathrm{g}$ protein) drops of rabbit anti-fumarate reductase antibody (IgG fraction) raised against catalytic dimer, as described by Lemire et al. (1983), or $10 \mathrm{mM}-\mathrm{PBS} / \mathrm{BSA}$ (control) for $2 \mathrm{~h}$ at room temperature in a moist chamber. The samples were washed twice with $10 \mathrm{mM}$-PBS/BSA, floated as before on a drop of $10 \mathrm{mM}-\mathrm{PBS} / \mathrm{BSA}$ for $2 \mathrm{~min}$, washed again with $10 \mathrm{~mm}-\mathrm{PBS} / \mathrm{BSA}$, and dried by touching the edge of the grid to filter paper. The samples were then floated as before on $100 \mu \mathrm{l}$ drops of protein A-gold for $1 \mathrm{~h}$. The grids were washed four times with $10 \mathrm{~mm}$-PBS. Samples were negatively stained with $1 \%$ sodium phosphotungstate, $\mathrm{pH} 7 \cdot 0$. The samples were examined in a Philips EM420 electron microscope operated at $100 \mathrm{kV}$.

Optical diffraction. Selected areas of micrographs of well preserved tubules were printed by contact onto Kodak electron microscope film (SO-163), masked, and their diffraction patterns recorded on a Polaron optical diffractometer (Johansen, 1975). Diffraction spots were measured and used to calculate the lattice dimensions for the tubule model.

\section{RESULTS}

\section{Tubule isolation}

We have developed a procedure for the separation of the tubular fraction from the inner and outer membrane fractions of $E$. coli harbouring the frd plasmid (Fig. 1). The procedure involves 
Table 1. Enzyme activities of membranes and tubules from E. coli HB101(pFRD63)

Specific activity values [units (mg protein) ${ }^{-1}$ ] are means of two determinations. PPB, Potassium phosphate buffer.

\begin{tabular}{|c|c|c|c|c|c|c|c|}
\hline \multirow[b]{4}{*}{ Source } & \multicolumn{5}{|c|}{ Fumarate reductase } & \multirow{4}{*}{$\begin{array}{c}\text { ATPase } \\
\text { specific activity }\end{array}$} & \multirow{4}{*}{$\begin{array}{l}\text { Nitrate reductase } \\
\text { specific activity }\end{array}$} \\
\hline & \multicolumn{3}{|c|}{ Specific activity } & \multirow{2}{*}{\multicolumn{2}{|c|}{$T_{\frac{1}{2}}(\min )^{*}$}} & & \\
\hline & \multirow{2}{*}{$\begin{array}{l}200 \mathrm{mM}- \\
\text { PPB (a) }\end{array}$} & \multirow{2}{*}{$\begin{array}{c}30 \mathrm{mM}- \\
\text { HEPES }(b)\end{array}$} & \multirow[b]{2}{*}{ Ratio $a / b$} & & & & \\
\hline & & & & $45^{\circ} \mathrm{C}$ & $\mathrm{pH} 8.6$ & & \\
\hline Tubules & 234 & 180 & $1 \cdot 3$ & $>120$ & $>120$ & $0 \cdot 10$ & $0 \cdot 10$ \\
\hline membranes & 196 & 164 & $1 \cdot 2$ & $>120$ & $>120$ & $0 \cdot 31$ & 0.43 \\
\hline
\end{tabular}

the gentle elution of tubules from a broken cell fraction prepared by lysozyme-deoxycholatefreeze-thaw treatment of stationary phase cells. Lysozyme-lysis was insufficient to release all the tubules, making it necessary to treat the vesicles with a low concentration of deoxycholate $(0.05 \%)$ followed by freeze-thawing to improve the yield. Approximately $50 \%$ of the fumarate reductase activity in the overproducing cells is localized in the tubules. We have been unable to devise a biochemical assay to distinguish tubules from inner membranes but electron microscopy and the SDS-PAGE profile (see Fig. 4) indicate a substantially enriched tubular fraction. Inner membrane contamination, as judged by the detection of low levels of typical inner membrane enzyme activities (Table 1), appears to be in the range of 15-20\%. However, it must be noted that the specific activities for the membrane-bound enzymes are reduced in the amplified membranes owing to dilution by the large amount of fumarate reductase (Weiner $e t$ al., 1984).

As outlined in Fig. 1, inner membranes are isolated from broken cells after the tubules are removed. The purified inner membranes contain approximately $30 \%$ of the total fumarate reductase. The supernatant fraction contains $18 \%$ of the fumarate reductase activity (Fig. 1). This activity consists of small fragments of tubules and aggregates of enzyme which do not sediment during centrifugation at $100000 \mathrm{~g}$ for $1 \mathrm{~h}$. In this procedure, as with the original cytoplasmic membrane purification procedure of Yamato et al. (1975), the outer membrane fraction was less than $5 \%$ contaminated with cytoplasmic membranes.

\section{Properties of fumarate reductase in tubules}

Previous reports from this laboratory (Lemire et al., 1982; Robinson \& Weiner, 1982) have documented two forms of fumarate reductase : a soluble catalytic dimer composed of the FRDA and FRDB subunits and a tetrameric holoenzyme composed of equimolar amounts of the FRDA, B, C and D subunits. These two enzyme forms can be distinguished by the anion dependence, and the alkali- and thermo-lability of the dimer form. We compared the inner membrane-bound form with the enzyme in the tubules; the two behaved similarly with respect to stability and anion stimulation (Table 1).

\section{Protein A-gold labelling of tubules and vesicles}

Tubules and inner membrane vesicles were specifically labelled with protein A-gold, using antibody (IgG fraction) raised against the catalytic dimer of fumarate reductase. The protein $\mathrm{A}-$ gold labelling is very specific, with few gold particles attached to non-tubule or nonmembranous material (Fig. $2 a, b$ ). Control samples labelled with PBS/BSA showed few nonspecifically bound gold particles, indicative of non-specific binding (data not shown). The antibody-specific attachment of the gold particles to the tubules confirms that these structures are assemblies of fumarate reductase, with the FRDA and B subunits on the surface. 


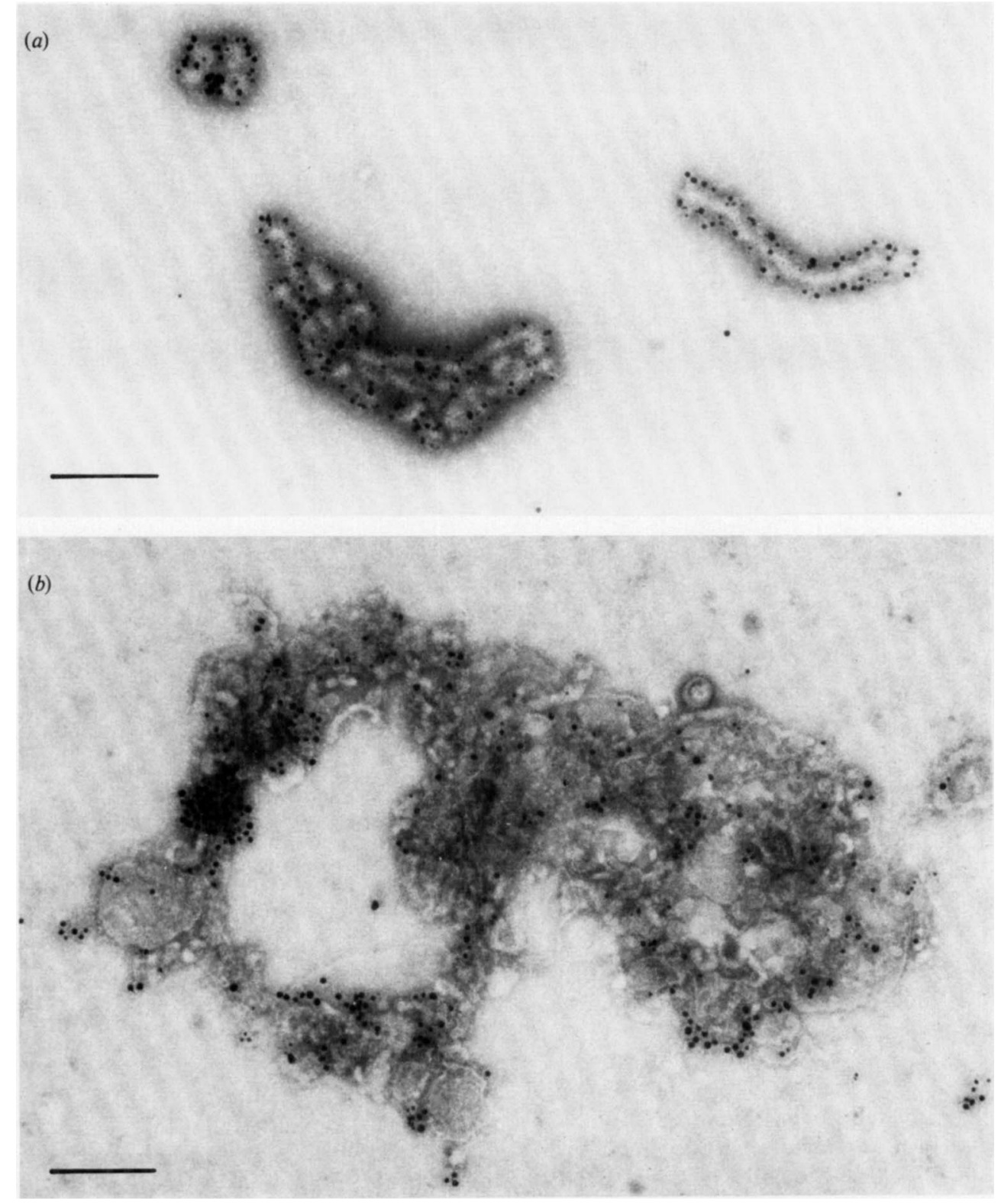

Fig. 2. Negative stain electron micrograph of $(a)$ tubules and $(b)$ inner membrane vesicles, treated as described for protein A-gold labelling. Bars, $200 \mathrm{~nm}$.

\section{Tubule structure}

We have used negative stain electron microscopy coupled with optical diffraction to develop an approximate model of tubule structure. The tubules are linear cylinders (Fig. $3 a$ ) densely covered with $5.3 \pm 0.3 \mathrm{~nm}$ spherical protein structures packed in a regular helical arrangement of 10 units per turn (Fig. 3b,c). From the model proposed by Lemire et al. (1983), it is presumed that these large knobs on the surface of the tubules are the $69 \mathrm{kDa}$ subunit. Also, the specificity of the protein A-gold labelling with the antibody raised against the catalytic dimer of fumarate reductase indicates that fumarate reductase is arranged in the tubules with the catalytic heads on the surface and with the anchor polypeptides embedded in the lipid interior. This arrangement 


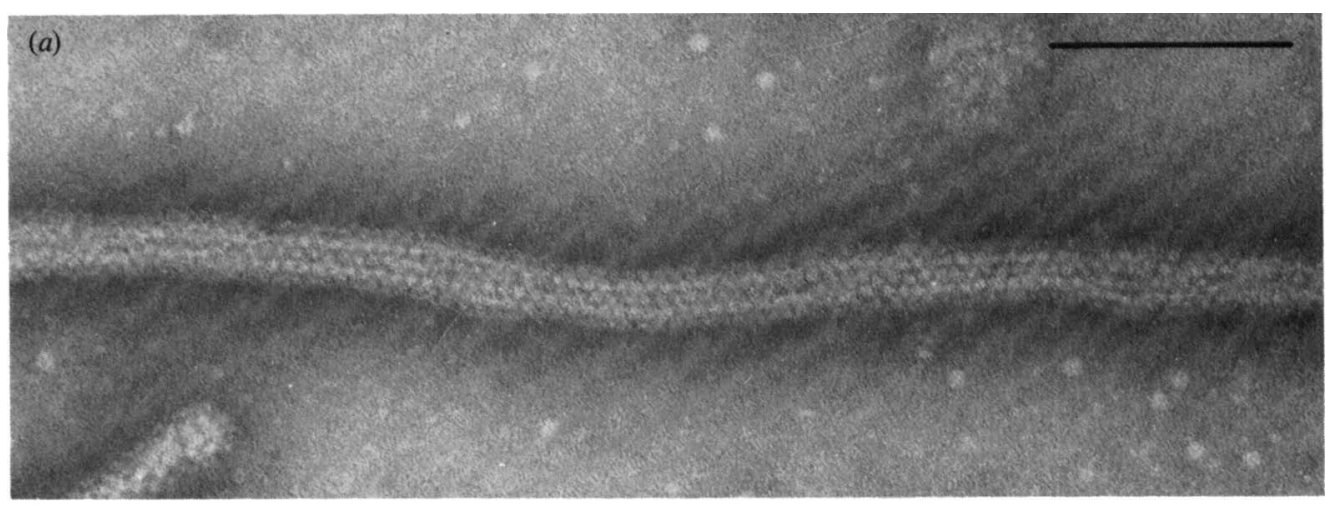

(b)

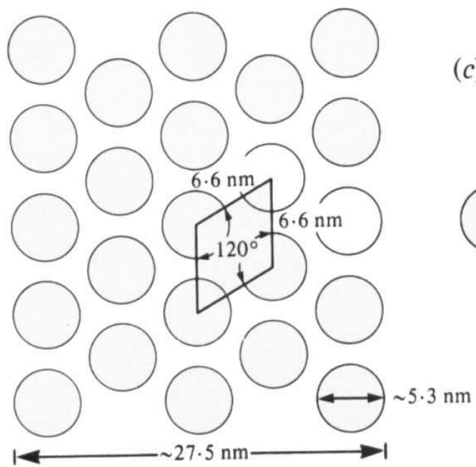

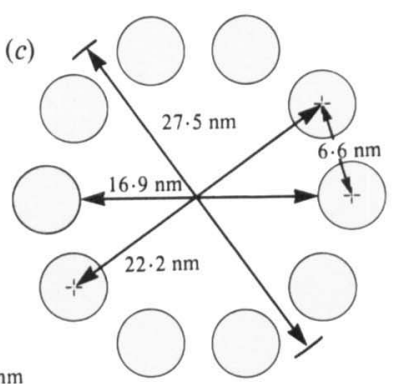

(c)

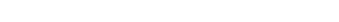

Fig. 3. (a) Negative stain electron micrograph of a purified tubule showing the helical arrangement of the fumarate reductase knobs. Bar, $100 \mathrm{~nm} .(b, c)$ A model based on electron micrograph measurements and optical diffraction studies for the helical arrangement of fumarate reductase in the tubules. (b) Longitudinal view of tubule and (c) cross-section of tubule.

is also supported by the observation that treatment of the tubules with $4.5 \mathrm{M}$-urea, which extracts the 69 and $27 \mathrm{kDa}$ subunits (Lemire et al., 1983) results in removal of the large spherical structures, leaving smooth, slightly swollen tubules (data not shown).

\section{Protein profile of isolated tubules}

The isolated tubules had an SDS-PAGE profile (Fig. $4 a$ ) similar to that reported for the Triton X-100 extract (Lemire et al., 1982), and highly purified for fumarate reductase compared to the initial cell envelopes (Fig. $4 b$ ). Based on the integration of Coomassie blue-stained SDSpolyacrylamide gels of tubules, up to $90 \%$ of the protein could be attributed to the four subunits of fumarate reductase. As reported previously (Lemire et al., 1982) fumarate reductase is a foursubunit enzyme with an equimolar ratio. A molar ratio of $1: 1: 0.8: 1$ was determined for the enzyme associated with the tubules, indicating that the unique assembly of the enzyme in the tubules is not due to an altered subunit composition. Based on the regular helical packing arrangement of fumarate reductase in the tubules it is unlikely that the contaminating polypeptides seen on the gel in Fig. 4(a) are actually components of the tubules; rather, we believe these represent the small amount of contamination by inner membrane in the preparation.

\section{Lipid/protein ratio of cytoplasmic membrane and tubules}

Samples of purified inner membranes and tubules were assayed for protein and lipid content (Table 2). It is apparent that the fumarate reductase-enriched inner membranes and tubules 


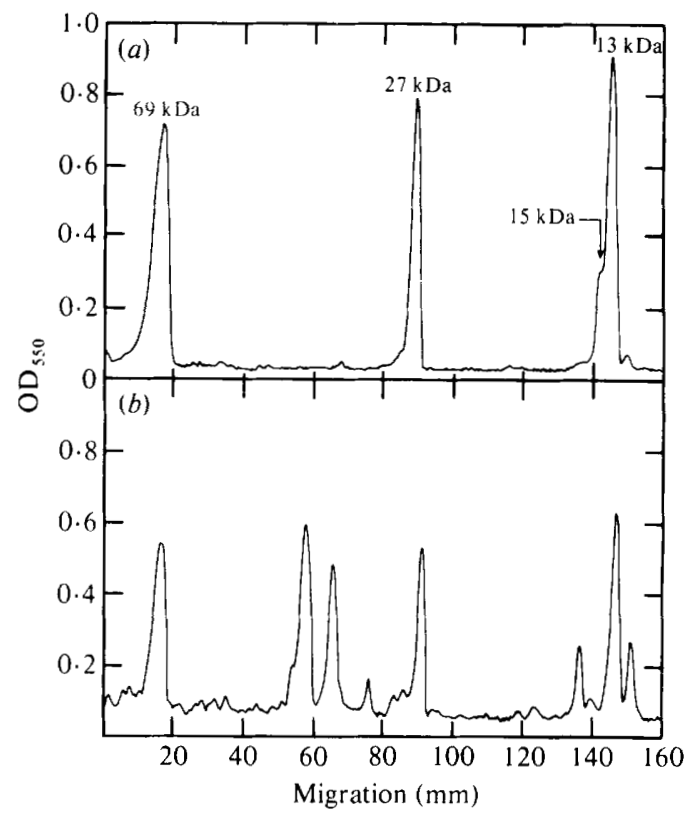

Fig. 4. Densitometric scans of the SDS-PAGE pattern of $(a)$ tubules and $(b)$ cell envelopes.

have a lower lipid/protein ratio than normal membranes (Table 2; Kaback, 1971). In fact, the tubules are over $75 \%$ protein, which presumably contributes to the unique structure.

\section{Phospholipid composition of cytoplasmic membranes and tubules}

The membranes from anaerobically grown $E$. coli $\mathrm{HB} 101$ contain phosphatidylethanolamine and phosphatidylglycerol as major phospholipids (Table 2). Crude membranes from strains overproducing fumarate reductase are enriched in cardiolipin; it accounts for $15-20 \%$ of the total lipid compared to $4 \%$ in normal strains (Weiner et al., 1984). Both isolated tubules and inner membrane fractions are enriched in cardiolipin, although the inner membranes are slightly more enriched (Table 2). These data indicate that the unique structure of the tubules is not due solely to the lipid composition, i.e. is not due to sequestration of the cardiolipin in the tubule fraction.

\section{Fatty acid composition}

As reported previously (Weiner et al., 1984; see Table 3), the fumarate reductase-enriched inner membranes showed decreases in the saturated fatty acid myristate $(14: 0)$, as well as in cyclopropanenonadecanoate $(19: \mathrm{cyc})$, compared to wild-type membranes. The tubules also showed decreases in these fatty acids, and in palmitate (16:0) (Table 3). Small increases were observed in the unsaturated fatty acid palmitoleate $(16: 1)$ and in cyclopropaneheptadecanoate $(17: \mathrm{cyc})$ in both tubules and inner membranes (Table 3$)$. The tubules isolated from the overproducing strains had a fatty acid profile slightly different from that of inner membranes from the same cells. The changes in the inner membrane and tubule fatty acid composition would tend to lower the phase transition temperature and fluidize the lipid component (Jain \& Wagner, 1980) compared to the membranes of the non-overproducing strain of HB101.

\section{Effect of a cardiolipin synthesis mutation on tubule structure}

The altered levels of cardiolipin in amplified strains prompted us to examine tubule formation in E. coli T1 PG, a strain deficient in cardiolipin synthesis (Pluschke et al., 1978). The mutant has only $4 \%$ of total lipid as cardiolipin, compared to $20 \%$ in normal overproducing strains, and also 
Table 2. Phospholipid composition of E. coli membranes containing normal and amplified levels of fumarate reductase

For HB101(pBR322) and HB101(pFRD63) the results of the lipid analyses are means of two determinations. The TIGP(pFRD63) and G800 lipid analyses were done once. The results for HB101(pBR322) are from Weiner et al. (1984).

\begin{tabular}{|c|c|c|c|c|c|c|c|}
\hline \multirow[b]{2}{*}{ Strain } & \multicolumn{4}{|c|}{ Phospholipid composition* } & \multirow[b]{2}{*}{$\begin{array}{c}\text { Lipid } \\
\text { concn } \\
\left(\mathrm{mg} \mathrm{ml}^{-1}\right)\end{array}$} & \multirow[b]{2}{*}{$\begin{array}{c}\text { Protein } \\
\text { concn } \\
\left(\mathrm{mg} \mathrm{ml}^{-1}\right)\end{array}$} & \multirow[b]{2}{*}{$\begin{array}{l}\text { Lipid/protein } \\
\text { ratio }\end{array}$} \\
\hline & PE & PG & centage & $\begin{array}{l}\text { Minor } \\
\text { components }\end{array}$ & & & \\
\hline HB101(pBR322) & & & & & & & \\
\hline $\begin{array}{l}\text { Total membrane } \\
\text { HB101(pFRD63) }\end{array}$ & 64 & 27 & 9 & - & $7 \cdot 3$ & $18 \cdot 2$ & $0 \cdot 40$ \\
\hline Cytoplasmic membrane & 62 & 8 & 27 & 3 & $6 \cdot 4$ & $18 \cdot 0$ & $0.36 \pm 0.01$ \\
\hline $\begin{array}{l}\text { Tubules } \\
\text { T1GP(pFRD63) }\end{array}$ & 63 & 12 & 21 & 4 & $6 \cdot 0$ & $24 \cdot 6$ & $0.22 \pm 0.02$ \\
\hline $\begin{array}{l}\text { Total membrane } \\
\text { G800 }\end{array}$ & 88 & 6 & 4 & 2 & ND & ND & ND \\
\hline Total membrane & 75 & 2 & 23 & - & ND & ND & ND \\
\hline
\end{tabular}

ND, Not determined.

* PE, phosphatidylethanolamine; PG, phosphatidylglycerol; DPG, diphosphatidylglycerol (cardiolipin).

Table 3. Percentage fatty acid content of anaerobically grown E. coli

The GLC analysis was done three times. The results obtained were similar; representative results are shown. The results for HB101 (pBR322) are from Weiner et al. (1984). The fatty acids are designated by the number of carbon atoms followed by the number of double bonds; cyc, cyclopropane.

\begin{tabular}{|c|c|c|c|c|c|c|c|c|}
\hline Strain & $14: 0$ & $15:$ cyc & $16: 0$ & $16: 1$ & $17:$ cyc & $18: 0$ & $18: 1$ & $19:$ cyc \\
\hline $\begin{array}{l}\text { HB101(pBR322) } \\
\text { Total membranes }\end{array}$ & 27.9 & $1 \cdot 3$ & 38.4 & $3 \cdot 3$ & 15.0 & 1.0 & 1.9 & $11 \cdot 1$ \\
\hline HB101(pFRD63) & & & & & & & & \\
\hline Cytoplasmic membrane & $19 \cdot 8$ & $0 \cdot 8$ & $38 \cdot 5$ & $10 \cdot 1$ & $25 \cdot 3$ & 0.4 & $2 \cdot 6$ & 1.9 \\
\hline Tubules & $17 \cdot 5$ & $1 \cdot 4$ & $35 \cdot 0$ & $10 \cdot 9$ & $29 \cdot 5$ & $0 \cdot 4$ & $2 \cdot 6$ & $2 \cdot 0$ \\
\hline
\end{tabular}

has lower levels of phosphatidylglycerol. These decreases were compensated by an increase in phosphatidylethanolamine to $88 \%$.

Although the mutant has only $4 \%$ cardiolipin, tubules are still formed to accommodate the overproduced fumarate reductase. However, the fumarate reductase is randomly oriented in these tubules (Fig. 5) and is not packed in the helical arrangement seen in HB101(pFRD63) (Fig. $3 a$ ). Although the SDS-PAGE profile indicates that the mutant tubules are highly enriched in fumarate reductase (data not shown), the enzyme has a low specific activity of approximately 50 units (mg protein $)^{-1}$. This low specific activity may be due to the instability of these tubules to freeze-thaw manipulations and to the presence of inactive enzyme.

\section{Tubule formation by an ampicillin hyper-resistant mutant}

We have reported the synthesis of a novel tubular organelle in response to high level amplification of plasmid-coded fumarate reductase (Weiner et al., 1984). G800, a $\beta$-lactamasehyper-producing strain of $E$. coli that is resistant to $800 \mu \mathrm{g}$ ampicillin $\mathrm{ml}^{-1}$, has amplified levels of fumarate reductase due to tandem duplication of the amp-frd region of the chromosome (Cole $\&$ Guest, $1979 a, b)$. We have now found that this method of amplification also results in tubule formation. When the cytoplasmic membrane-binding capacity for fumarate reductase becomes saturated, the G800 cells produce the long tubular assemblies of helically packed enzyme and lipid. During the exponential phase of growth $(24 \mathrm{~h})$ these structures appear indistinguishable from the tubules observed in strains harbouring a frd multicopy plasmid (Weiner et al., 1984), as judged by negative stain electron microscopy of lysed cells. However by $72 \mathrm{~h}$ (stationary phase) 

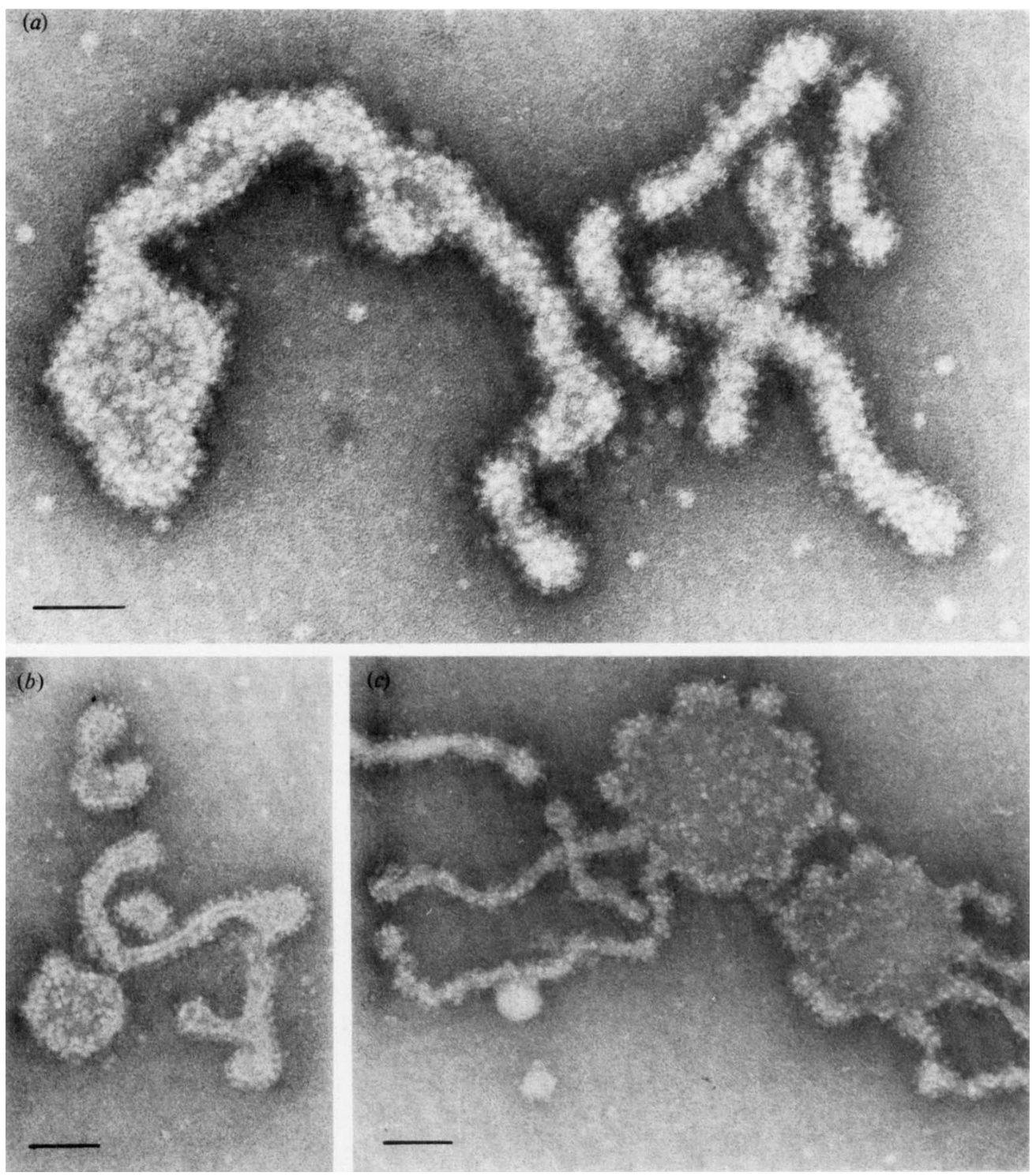

Fig. 5. Negative stain electron microscopic views of tubules from a cardiolipin-synthesis mutant, E. coli TIGP(pFRD63). Bars, $50 \mathrm{~nm}$.

only small fragments of tubules are visible in the cytoplasm and the total activity of fumarate reductase is reduced by up to $50 \%$. This loss of activity accompanied by tubule breakdown is not observed with the plasmid-coded enzyme, indicating an inherent difference in the two forms of amplified fumarate reductase. The membranes from these cells have an increased amount of cardiolipin, as seen in the normal overproducing strains (Table 2), indicating the lipid composition is not responsible for the instability of the G800 tubules.

\section{DISCUSSION}

Little information is available on the response of bacterial cells to very high levels of expression of integral membrane proteins. Our studies with the terminal electron transfer 
enzyme fumarate reductase suggest that the cells respond to this stress by synthesizing a novel intracellular organelle composed of phospholipid and enzyme (Weiner et al., 1984).

The method we have devised for isolating tubules, relatively free of inner and outer membrane, relies on gentle hypotonic lysis of bacterial cells. Tubules not released in the soluble fraction were eluted from the spheroplasts by a combination of mild detergent and freeze-thaw treatments. Our inability to separate tubules from inner membranes routinely by sucrose density gradient centrifugation required that the initial preparation contained as few inner membranes as possible. The isolated tubules were further purified by centrifugation on a sucrose cushion. The yield of fumarate reductase in the tubules is about $50 \%$, a value in good agreement with the doubling of membrane material observed in overproducing cells; $90 \%$ of the tubular protein is fumarate reductase. The physical properties and catalytic behaviour of tubule-bound fumarate reductase are indistinguishable from cytoplasmic membrane-bound enzyme or soluble holoenzyme. Tubules have a phospholipid composition and fatty acid profile similar to inner membranes from amplified strains. The only observed difference is in the lipid to protein ratio. Tubules have a much lower ratio $(0.25)$ than the cytoplasmic membranes $(0.35)$. This difference would suggest that the tubules are much denser than the cytoplasmic membranes, but we have been unable to separate tubules from vesicles by sucrose density gradient centrifugation.

Isolated tubules display a regular helical packing arrangement of exposed spherical protein structures when observed by electron microscopy. Based on protein A-gold labelling and other experiments (Lemire et al., 1983) we have shown that the spheres are the catalytic subunits of fumarate reductase. These results suggest that the anchor subunits are buried within the tubules together with the phospholipid fatty acyl side chains.

The mechanism of tubule assembly remains to be elucidated, but as a first step we have examined the role of cardiolipin, since the tubules and cytoplasmic membranes of overproducing cells are highly enriched in this phospholipid. A transformed mutant, $E$. coli T1GP(pFRD63), with a defect in cardiolipin biosynthesis still produced tubules, but these tubules differed morphologically from the wild-type, displaying a variable and irregular arrangement of the fumarate reductase. Also, the enzyme in these structures was unstable to freeze-thaw manipulations. These results suggest that cardiolipin plays a role in the assembly of fumarate reductase in the tubules and regulates the packing of the protein in these structures.

The expression of fumarate reductase can be amplified in at least two ways. First, selection of ampicillin hyper-resistant strains, in an ampAl genetic background, leads to tandem duplications of the $a m p-f r d$ region, resulting in an increased frd gene dosage (Cole \& Guest, $1979 a, b)$. A second approach is to use multicopy plasmids expressing the cloned frd operon (Cole \& Guest, 1980; Lohmeier et al., 1981; Lemire et al., 1982, 1983). In this paper we have shown that both methods of amplification result in tubule formation. However, the tubules formed in response to ampicillin hyper-resistance are qualitatively more unstable than those formed in response to the plasmid-coded genes. Indeed it did not prove possible to isolate tubules from G800 by the protocol reported in this paper. The reason for the instability is unclear but may be related to the $a m p A l$ mutation. This mutation is a frame shift in the overlapping amp attenuator- $f r d D$ region (Jaurin \& Grundström, 1981), and causes the hydrophobic FrdD subunit to be covalently-linked to $\beta$-lactamase. We have been unable to identify the frdD-ampC fusion protein in membrane preparations (B. D. Lemire, S. T. Cole \& J. H. Weiner, unpublished), even though the $\beta$-lactamase can be detected in the membrane protein profile.

The correlation of tubule formation with intrinsic membrane protein amplification remains to be determined, but similar structures have been observed with $F_{0} / F_{1}$ ATPase (Von Meyenburg et al., 1984) and in strains overproducing glycerol-3-phosphate acyl transferase and pyridine nucleotide transhydrogenase (R. Bell \& P. D. Bragg, personal communications). The ability to isolate tubules, consisting of a nearly homogeneous membrane protein and lipid, may be an important biotechnological approach for isolating cloned membrane proteins.

We thank Professor J. R. Guest for providing strain G800 and Dr E. P. Kennedy for providing strain T1GP. We also thank Dr R. N. McElhaney, Dr R. Lewis and Dr M. Poznansky for help with phospholipid analysis, L. Rodseth for the optical diffraction analysis and R. D. Bradley for assistance with the electron microscopy and photography. We also thank Gillian Shaw for excellent technical assistance. 
This work was funded by grants from the Medical Research Council of Canada to J.H.W. and D.G.S. M.L.E. received support from the Alberta Heritage Foundation for Medical Research.

\section{REFERENCES}

BLIGH, E. C. \& DYER, W. J. (1959). A rapid method of total lipid extraction and purification. Canadian Journal of Biochemistry and Physiology 37, 911-917.

COLE, S. T. \& GUEST, J. R. (1979a). Amplification and aerobic synthesis of fumarate reductase in ampicillin-resistant mutants of Escherichia coli K-12. FEMS Microbiology Letters 5, 65-67.

Cole, S. T. \& Guest, J. R. (1979b). Production of a soluble form of fumarate reductase by multiple gene duplication in Escherichia coli K12. European Journal of Biochemistry 102, 65-71.

COLE, S. T. \& Guest, J. R. (1980). Genetic and physical characterization of lambda transducing phages $(\lambda f r d A)$ containing the fumarate reductase gene of Escherichia coli K12. Molecular and General Genetics 78, 409-418.

Dickie, P. \& Weiner, J. H. (1979). Purification and characterization of the membrane-bound fumarate reductase from anaerobically grown $E$. coli. Canadian Journal of Biochemistry 57, 813-821.

FRENS, G. (1973). Controlled nucleation for the regulation of the particle size in monodisperse gold solutions. Nature, London 241, 20-22.

Gander, G. W., Jensen, R. G. \& Sampugna, J. (1962) Analysis of milk fatty acids by gas-liquid chromatography. Journal of Dairy Science 45, 323-328.

GRUNDSTRÖM, T. \& JAURIN, B. (1982). Overlap between $a m p C$ and frd operons on the Escherichia coli chromosome. Proceedings of the National Academy of Sciences of the United States of America 79, 1111 1115.

HADdock, B. A. \& Jones, C. W. (1977). Eacterial respiration. Bacteriological Reviews 41, 47-99.

JAIN, M. K. \& WAGNER, R. C. (1980). Introduction to Biological Membranes. New York: John Wiley \& Sons.

JAURIN, B. \& GRUNDSTRöm, T. (1981). ampC cephalosporinase of Escherichia coli $\mathrm{K}-12$ has a different evolutionary origin from that of $\beta$-lactamases of the penicillinase type. Proceedings of the National Academy of Sciences of the United States of America 78, 4897-4901.

JOHANSEN, B. V. (1975). Optical diffractometry. In Principles and Techniques of Electron Microscopy, Biological Applications, vol. 5, pp. 114-173. Edited by M. A. Hayat. New York: Van Nostrand Reinhold.

KaBACK, H. R. (1971). Bacterial membranes. Methods in Enzymology 22, 99-120.

LAEMMLI, U. K. (1970). Cleavage of structural proteins during assembly of the head of bacteriophage T4 Nature, London 227, 681-685.

LEMIRE, B. D., Robinson, J. J. \& WeINER, J. H. (1982). Identification of the membrane anchor polypeptides of $E$. coli fumarate reductase. Journal of Bacteriology 152, 1126-1131.

Lemire, B. D., Robinson, J. J., Bradley, R. D., SCRABA, D. G. \& WeINER, J. H. (1983). Structure of fumarate reductase on the cytoplasmic membrane of Escherichia coli. Journal of Bacteriology 155, 391397.

Lohmeier, E., Hagen, D. S., Dickie, P. \& Weiner, J. H. (1981). Cloning and expression of the fumarate reductase gene of Escherichia coli. Canadian Journal of Biochemistry 59, 158-164.

Markwell, M. A. K., HaAs, S. M., Bieber, L. L. \& TOLBERT, N. E. (1978). A modification of the Lowry procedure to simplify protein determination in membrane and lipoprotein samples. Analytical Biochemistry 87, 206-210.

Owen, P., Graeme-Cook, K. A., Crowe, B. A. \& CoNDON, C. (1982). Bacterial membranes: preparative techniques and criteria of purity. In Techniques in Lipid Membrane Biochemistry, vol. B4, pp. 1-69. Edited by T. R. Hesketh, H. L. Kornberg, J. C. Metcalfe, D. H. Northcote, C. I. Pogson \& K. F. Tipton. New York: Elsevier/North-Holland.

Pluschke, G., Hirota, Y. \& Overath, P. (1978). Function of phospholipids in Escherichia coli. Journal of Biological Chemistry 253, 5048-5055.

Raheja, R. K., Kaur, C., Singh, A. \& Bhatia, I. S. (1973). New colorimetric method for the quantitative estimation of phospholipids without acid digestion. Journal of Lipid Research 14, 695-697.

Robinson, J. J. \& WeINeR, J. H. (1982). Molecular properties of fumarate reductase isolated from the cytoplasmic membrane of Escherichia coli. Canadian Journal of Biochemistry 60, 811-816.

RoTH, J. (1983). The colloidal gold marker system for light and electron microscopic cytochemistry. In Techniques in Immunocytochemistry, vol. 2, pp. 217284. Edited by G. R. Bullock and P. Petrusz. New York: Academic Press.

ROTH, J., BENDAYAN, M. \& ORCl, L. (1978). Ultrastructural localization of intracellular antigens by the use of protein A-gold complex. Journal of Histochemistry and Cytochemistry 26, 1074-1081.

SPencer, M. E. \& Guest, J. R. (1974). Proteins of the inner membrane of $E$. coli: changes in composition associated with anaerobic growth and fumarate reductase amber mutations. Journal of Bacteriology $117,947-953$

Von Meyenburg, K., Jorgensen, B. B. \& VAN DeURS, B. (1984). Physiological and morphological effects of overproduction of membrane-bound ATP synthase in Escherichia coli K-12. EMBO Journal 3, 1791-1797.

Weiner, J. H., LemiRe, B. D., Elmes, M. L., BradLEy, R. D. \& Scraba, D. G. (1984). Overproduction of fumarate reductase in Escherichia coli induces a novel intracellular lipid-protein organelle. Journal of Bacteriology 158, 590-596.

Yamato, I., ANRakU, Y. \& Kirosawa, K. (1975). Cytoplasmic membrane vesicles of Escherichia coli. I. A simple method for preparing the cytoplasmic and outer membranes. Journal of Biochemistry 77, $705-718$ 